\title{
Relationship of Parties to Collective Bargaining and Industrial Relations Environment in Public Universities in Kenya
}

\author{
Dr. Patrick J.Akhaukwa \\ Acting Registrar (RIO), Jaramogi Oginga Odinga University of Science and Technology \\ pakhaukwa2004@yahoo.com (corresponding author) \\ Dr. Loice Maru \\ Senior lecturer, Moi University \\ Icmaru@yahoo.com \\ Prof. John Byaruhanga \\ Associate Professor, Masinde Muliro University of Science and Technology \\ byaruhangajohn@ymail.com
}

Doi:10.5901/mjss.2013.v4n11p705

\section{Abstract}

This article examines the effect of relationship of parties to collective bargaining on industrial relations environment in public universities in Kenya. The data used in analysis is based mainly on stratified probability sample of 322 respondents interviewed in 2012 in the three public universities in Kenya. Expert judgment was used to determine the validity while Cronbach alpha coefficient was used to determine reliability of research instruments. Qualitative and quantitative data was analyzed using both descriptive and inferential statistics. Exploratory factor analysis was performed to reduce large number of variables for further analysis. Linear regression analysis was employed to determine the effect of relationship of parties to collective bargaining on industrial relations environment. The result revealed that relation of parties to collective bargaining had a significant effect on industrial relations environment $(\beta=0.531, p<0.05)$. The study recommends that parties to collective bargaining should reconsider their strategies for engagement in order to enhance their relationship.

Keywords: relationship of parties, collective bargaining, Industrial relations environment, Public universities, Academic staff, Kenya

\section{Introduction}

Sound industrial relations is one in which relationships between management and employees on the one hand, and between them and the State on the other, are more harmonious and cooperative than conflictual (Silva, 1998). Studies have demonstrated the positive effects of good industrial relations on company performance, efficiency and productivity which underscore the importance of industrial relations in organizational success (Fashoyin, 2004; Pyman et al., 2010). It is argued that positive perception of organizational prestige, positive attitudes towards supervisors, reduced absenteeism, turnover and conflict, innovation, customer satisfaction, and service or product quality are some of the outcomes that have been found to be associated with a favourable industrial relations environment (Lee, 2009). Industrial relations therefore contribute to labour peace and social stability and, in turn, economic and social development (Fashoyin, 2004).

One key approach used to enhance industrial relations environment in organizations is social partnership which facilitates collective bargaining between parties (Sealy, 2003). Silva (1998) notes that through collective bargaining the government, the workers' representative and employers' organizations as independent and equal partners, consult with each other on labour market and related issues which are within their spheres of competence, and jointly formulate and implement policies on such issues. Fashoyin, (2004) on the other hand view collective bargaining to be an important mechanism that can reduce industrial conflict by finding peaceful and orderly procedures to resolve potentially damaging disputes. The relationship of the parties to collective bargaining is therefore critical.

While researchers have discussed a great deal on the importance of collective bargaining on industrial relations environment, there is dearth of concrete information on how relationship of parties to the process impact on industrial 
relations environment in public universities in Kenya. Universities worldwide are regarded as centres of excellence and there immense contribution to national development cannot be gainsaid. Absence of favorable industrial relations environment can therefore be an impediment to stability hence affecting the quality of the training and consequently the overall national development. With the rapid expansion of higher education in Kenya, there has been a great deal of interest in the stability of institutions of higher learning.

This article seeks to establish the effect of the relationship of parties to collective bargaining on industrial relations environment in public universities in Kenya. The analysis rests on the premise that relationship of parties to collective bargaining has a significant effect on industrial relations environment. It is anticipated that the knowledge gained from this study will contribute to the existing body of knowledge in the area of collective bargaining and industrial relations environment in both public and private sectors in Kenya. It will also shed light and create awareness to employers, employees, trade unions and the government on industrial relations environment issues. The findings will form a basis for policy formulation as well serve as a point of reference and stimulate more research on industrial relations.

\section{Literature review}

This section reviews literature on the concept of industrial relations environment and relationship of parties to collective bargaining.

\subsection{Industrial relations environment}

Industrial relations may be described as being concerned with the rules, processes and mechanisms through which the relationship between employers and employees and their respective representatives, as well as between them on one hand and the State and its agencies on the other, is regulated (Sliva, 1998). Anderson et al. (1989), concur with the above definitions by arguing that industrial relations is not restricted to union-management relations nor does it only consist of collective bargaining process. Employees, managers, owners, and self-employed entrepreneurs are all part of industrial relations system and are influenced or constrained by it. Similarly, Mahabir- Wyatt (2006) defines industrial relations as the relations between employers and those employed in an industrial setting, taking into account the resultant reaction from stakeholders directly affected, such as the State.

According to Anderson et al. (1989), industrial relations does not refer solely to the role of unions and collective bargaining in employment but also encompasses the role and impact of personnel policies developed by employers; the scope and impact of employment related legislation enacted by the government; and the role of labour markets in establishing the terms and conditions of employment for individuals across occupations, industries and regions. However, Armstrong (2006) differs with the above definitions and posits that industrial relations is essentially about the dealings between management and trade unions. Consistent with the above definitions, industrial relations therefore focuses on outcomes most closely related to the interaction of employees and employers and the "web of rules" concerning employment that they and their organizations, along with government, establish to govern employeremployee relations (Fiorito, 2011).

A study by Sliva (1998) revealed that industrial relation is important because it seeks to balance the economic efficiency of organizations with equity, justice and the development of the individual, to find ways of avoiding, minimizing and resolving disputes and conflict and to promote harmonious relations between and among the actors directly involved, and society as a whole. The study further reported that a sound industrial relations environment in an enterprise is essential to a number of issues which are critical to employers, employees and the community. For instance, the efficient production of goods and services depends to an extent on the existence of a harmonious industrial relations climate. Kuruvilla and Erickson (2002) observed that the goal of the industrial relations system was to maintain labor peace and, more generally, industrial stability. They further explain that industrial relation helps in containing industrial conflict hence making it difficult for the parties to go on strike by mandating some form of third party dispute resolution, and by attempting to foster responsible trade unionism rather than militant trade unionism. As a result industrial peace or stability is realized, which is a pre-requisite for economic development in many of the countries.

On the other hand industrial relations environment refers to the atmosphere, norms, attitudes and behaviours reflecting and underpinning how workers, unions and managers interact collectively with each other in the workplace, which in turn, affects workplace outcomes (Kersley et al., 2006). According to Pyman et al. (2010), workplace environment and the contextual factors are sometimes described as the industrial relations climate, and this concept has been used to explain behavior and attitudes in the workplace, and interactions between unions, employees and 
employers. Industrial relations environment therefore depicts the state and quality of union-management relations in an organization. Industrial relations environment can therefore be described as a function of work practices (the organization of work) and employment practices -the management of people , and thus may be linked to organizational performancecompany and worker outcomes (Boxall and Macky, 2009).

Some studies have shown that favourable perceptions of industrial relations environment are positively associated with commitment to both the employer and the union. These studies have further indicated that favorable perceptions of the industrial relations environment allows for commitment of employer and employee because of cognitive consistency between the role of employee and union member in workplaces with more cooperative union-management relations (Redman and Snape, 2006). Industrial relations environment has therefore been identified as a key mediating factor in the link between high-performance work systems and organizational performance and effectiveness (Kersley et al., 2006). Other outcomes that have been found to be associated with a favourable industrial relations climate include: positive perceptions of organizational prestige, positive attitudes towards supervisors, reduced absenteeism, turnover and conflict, innovation, customer satisfaction, and service or product quality (Lee, 2009).

According to Khan (2006), a stable industrial relations climate is therefore vitally important for the economic growth of any country. This observation is consistent with a study by Goolsarran (2006) which revealed that the climate of labour and industrial relations in any country has a direct impact on its economic and social development, which requires a favorable environment in which labour relations can be conducted in an orderly and responsible manner.

Another study by Pyman et al. (2010) concluded that employees' perceptions of the industrial relations environment are more likely to be favourable if they have access to direct-only voice arrangements. Where management is perceived by employees to oppose unions (in unionized workplaces), the industrial relations environment is more likely to be reported as poor. Wan (1997) therefore identified six dimensions of industrial relations that can be used to measure industrial relations environment namely: union management c-o-operation, mutual regard, apathy, joint participation, hostility and trust. This study will therefore adopt with modification Wan's six dimension model to measure industrial relations environment in public universities in Kenya.

\subsection{Relationship of parties to collective bargaining and industrial relations environment}

The parties to the process of collective bargaining include employer or employers' associations and employees' representative or a trade union and government (Dunlop, 1958). Studies of industrial relations systems have shown that these three actors are generally viewed as exclusive to the industrial relations and workers' rights arena (Egels-Zanden et al., 2009). Fashoniy, (2004), found that willingness to consult or negotiate, and generally to engage in social dialogue is fundamental to effective participation. The study further reported that as a process for interest mediation in distributive conflicts, the consultative mechanism can only derives its legitimacy, hence its relevance, from the extent to which it represents key stakeholders in the industry.

Pyman et al. (2010) found that co-operative relationships require active engagement and maintenance of the relationship from both parties, but this entails significant time and resource demands. It also requires a concerted effort from all the three parties-workers, unionists and employers. The study suggested that employers should regard their employees and union representatives as useful partners and should have a better feel for how organizational members perceive the company's policies and practices. Similarly, workers and unionists have to understand that their well-being is linked to that of their companies (Wan et al., 1997). The establishment of trust between the parties and the existence of mutual recognition are also prerequisites of co-operative relationships (Peetz and Frost, 2007).

Flippo (1984), explain that parties to collective bargaining have a basic obligation to establish a constructive relationship of working in harmony in the advancement of labour management peace. Such relationship would include: labour unions management acceptance of each other as responsible parties in collective bargaining; acceptance by both parties of free-enterprise system with its concomitant obligations and the authority of private ownership and private operation of business organization; an emphasis upon problem-solving approach with de-emphasis upon excessive legalism; and, an awareness of basic obligations to principals, who include employees, stakeholders, customers, and the public. Rehman (2003) asserts that negotiation of a balanced settlement between workers and employers is of vital importance for the management as well as the trade union, because on one hand it helps in creating good and congenial working environment thus resulting in improved productivity, while on the other hand, it enables the organization to achieve viability and productivity.

Jain et al. (2004), observes that the negotiating team should consist of representative of both workers and employers with adequate qualities, job knowledge and skill for negotiation. They should not only truly represent the two 
parties but also have full authority to speak for them and make decisions. Both parties should be equally keen to reach a win-win agreement and if this can be achieved, the future relationships between parties are more likely to be harmonious (Armstrong, 2006). According to Dubin (1957), the determination of wages, hours, and working conditions is a central function in the whole employment relationship between employer and employees. If this function is not fulfilled there will be no employer-employee relationship. Therefore no single group has as much power regarding wages, hours, and working conditions as would be true in a bilateral or unilateral determination of them.

The acts or omissions of one party may be able to sour employee relations, but no matter how constructive a union wishes to be, or how strong it may be organizationally, a co-operative environment is likely to require that management engages constructively with the union, and vice versa (Bryson and Wilkinson, 2001). Hence, under conditions of mutual trust, management and labor have the potential of better understanding organizational goals and the interdependence of the parties. A relationship of trust is illustrated when parties work together in creating options that are mutually gainful and maximize success for everyone - often referred to as the "our way" approach (Caverley and Cunningham, 2006). Likewise Greene et al. 2000; Guest and Peccei (2001), suggest that it was important for the union representative to establish trust with union members.

Gatchalian (1998) concluded that Quality and productivity are the critical improvement areas where companies can improve their competitive edge. This is only possible when there is a cooperative and harmonious relationship between the principal partners in production - workers and managers. Also, the terms of the working relationship must be defined and settled by bargaining with each other. According to Farnham (2000), a precondition for collective bargaining is the existence of independent parties whose members are willing to delegate authority to the representative organizations. In such environment, collective agreements are generally concluded through dialogue and compromise between trade unions and employers' representatives, but mediation or arbitration are used when necessary.

Foster et al. (2009) shows that unless employers are prepared to engage in dialogue with employees or third parties and unless the benefits to be gained from such a dialogue are more widely accepted it is unlikely they will engage in collective bargaining. A case study done by ILO/PROMALCO (2005) indicates a number of factors that have been instrumental in the success of labour - management partnerships. These include top management commitment, efforts to build trust and a philosophy and a new set of values and joint commitment to the success of the enterprise.

Evidence from the literature reviewed shows that the parties to the collective bargaining must regard each other as useful partners and be willing to negotiate for negotiations to succeed. Similarly, the parties must establish trust between them and must work in harmony. They should also have legitimacy of representation and acceptable by both parties. Besides, they must show commitment and bargain in good faith. This will ensure that there is co-operative relationship between the parties to collective bargaining. However, one conspicuous lacuna in this body of literature is that not enough attention has been accorded to the issues relating to the effect of parties to collective bargaining and industrial relations environment.

\section{Methodology}

The study used explanatory research design to establish the effect of relationship of parties to collective bargaining on industrial relations environment. The universe of the study was academic staff who were members of Universities Academic Staff Union (UASU) from universities in Kenya. The population was stratified by designations to reflect the distribution of various categories of academic staff and a total of 322 respondents were selected to participate in the study. Academic staff who were holding managerial positions, those on study leave or leave of absence and those serving on contractual terms were excluded from the study. The research was conducted between April and July 2012.

The survey instrument was adopted from the 2010 Industrial Relations Climate, Employee Voice and Managerial Attitudes to Unions Survey conducted in Australia (Pyman et al., 2010), Industrial Relations Climate Survey in the Manufacturing sector in Singapore (Wan et al., 1997) and Industrial Relations Climate and Staff Survey in the Fire Service in United Kingdom (Redman and Snape, 2006). Original questions from the above studies were modified to conform to the objective of the study and to take into consideration the Kenyan contexts. Using the pilot data, the reliability of 0.8419 and 0.8115 was established for the instruments. The reliability was calculated using Cronbach's Coefficients Alphas.

The dependent variable was based on responses on eight items which were rated on a five point Likert type scale ranging from " $1=$ strongly disagree" to " $5=$ strongly agree", with " 3 " being a neutral midpoint. The following eight measures guided this study in assessing the industrial relations environment: management union cooperation, mutual regard for each other, willingness of the parties to confer, willingness of management to facilitate union operations, joint 
participation in decision making, dispute resolution and management attitude towards the union. In addition, relationship of parties to collective bargaining was assessed on eight items namely; willingness to consult, respect between parties, good faith bargaining, representations and negotiation skills. Others included; regard of each other as partners, employees view of workers representatives and mutual regard for each other. The respondents were asked to assess the relationship of the parties to collective bargaining process on a five point Likert scale ranging from "1= strongly disagree" to " $5=$ strangely agree".

The data was analyzed to provide frequencies, percentages, means and standard deviation to describe the population. Both independent and dependent variables were subject to factor analysis to reduce large number of explanatory variables and screen variables for further analysis. Factor scores from factors with eigenvalues greater than one were considered as dependent and independent variables. Regression analysis was used to determine the effect of relationship of parties to collective bargaining on industrial relations environment in public universities in Kenya.

\section{Findings}

\subsection{Industrial Relations Environment}

As illustrated in Table 1, the findings of this study revealed that majority $(67.7 \%, f=218)$ of respondents strongly disagreed or disagreed that union and management cooperates well while $13 \%(f=42)$ were neutral. A further $19.3 \%$ $(\mathrm{f}=62)$ strongly agreed or agreed that union and management cooperates well at work. Majority $(66.7 \%, \mathrm{f}=214)$ of respondents strongly disagreed or disagreed that mutual regard existed between management and union, 19.3\% ( $f=62$ ) were neutral while $14 \%(f=45)$ strongly agreed or agree.

Table 1. Analysis of the Items on Industrial Relations Environment

\begin{tabular}{|c|c|c|c|c|c|c|c|c|c|}
\hline \multirow{2}{*}{ Item } & \multicolumn{9}{|c|}{ Rating } \\
\hline & $\mathrm{SD} \%(\mathrm{~F})$ & $\mathrm{D} \%(\mathrm{~F})$ & $\mathrm{N} \%(\mathrm{~F})$ & $A \%(F)$ & $\mathrm{SA} \%(\mathrm{~F})$ & M & SD & S & K \\
\hline $\mathrm{A} 1$ & $17.1(55)$ & $50.6(163)$ & $13.0(42)$ & $17.4(56)$ & $1.9(6)$ & 2.36 & 1.018 & .652 & -.391 \\
\hline $\mathrm{A} 2$ & $7.8(25)$ & 58.9(189) & $19.3(62)$ & 12.1(39) & $1.9(6)$ & 2.41 & .869 & .897 & .469 \\
\hline A3 & $9.3(30)$ & $62.1(200)$ & $12.4(40)$ & $14.6(47)$ & $1.6(5)$ & 2.37 & .898 & .941 & .321 \\
\hline A4 & $19.4(62)$ & $57.8(185)$ & $12.5(40)$ & $8.4(27)$ & $1.9(6)$ & 2.16 & .896 & 1.029 & 1.110 \\
\hline $\mathrm{A} 5$ & $13(42)$ & 57.5(191) & $15.2(49)$ & $11.8(38)$ & $2.5(8)$ & 2.33 & .933 & .913 & .504 \\
\hline A6 & $16.2(52)$ & $59.5(146)$ & $14.6(47)$ & $9.3(30)$ & $0.3(1)$ & 2.18 & .824 & .798 & .516 \\
\hline A7 & $20.2(65)$ & $45.5(146)$ & $15.0(48)$ & $15.9(51)$ & $3.4(11)$ & 2.37 & 1.079 & .653 & -.379 \\
\hline A8 & $12.7(41)$ & 53.4(172) & $13.0(42)$ & 19.3(62) & $1.6(5)$ & 2.43 & .991 & .627 & -.483 \\
\hline
\end{tabular}

$\mathrm{n}=322$. Key: $\mathrm{SD}=$ strongly disagree; $\mathrm{D}=$ disagree; $\mathrm{N}=$ neither; $\mathrm{A}=$ agree; $\mathrm{SA}=$ strongly agree; $\mathrm{M}=$ =mean; $\mathrm{SD}=$ standard deviation; $\mathrm{S}=$ skewness; $\mathrm{K}=$ kurtosis; $\mathrm{F}=$ frequency; $\mathrm{A} 1=$ Union and management cooperates well, $\mathrm{A} 2=$ Mutual regard between management and the union exist, $\mathrm{A} 3=$ Union and management are willing to confer; $\mathrm{A} 4=$ Management facilitates union operations; $\mathrm{A} 5=$ Union participates in decision making; $A 6=$ Management and union resolve disputes amicably; $A 7=$ Management's attitude towards the union is favourable; A8=Management and union share information freely

\section{Source: Survey data 2012}

On the other hand, $71.4 \%(\mathrm{f}=230)$ of the respondents strongly disagreed or disagreed that union and management are willing to confer, while $12.4 \%(f=40)$ were neutral and $16.2 \%(f=52)$ strongly agreed or agreed. Further, $77.2 \%(f=247)$ of the strongly disagreed or disagreed that management facilitates union operations, $12.5 \%(f=40)$ were neutral and 10.3 $\%(\mathrm{f}=33)$ strongly agreed or agreed with the above statement. Likewise, $70.5 \%(\mathrm{f}=227)$ of the respondents strongly disagreed or disagreed that union was involved in decision making while $15.2 \%(f=49)$ were neutral. Further $14.4 \%(f=46)$ indicated that they strongly agreed or agreed that union participated in decision making.

On dispute resolution, an overwhelming majority $(75.7, \mathrm{f}=243)$ strongly disagreed or disagreed that management and the union resolve disputes amicably, 14, $6 \%(f=47)$ were neutral and $9.6 \%(f=31)$ strongly agreed or agreed. In addition, $65.7 \%$ ( $f=211$ ) strongly disagreed or disagreed that management's attitude towards the union was favourable, $15 \%(f=48)$ were neutral while $19.3 \%(\mathrm{f}=62)$ strongly agreed or agreed with the above statement. On sharing of information, $66.1 \%(\mathrm{f}=213)$ strongly disagreed or disagreed that union and management share information freely, while $13 \%(\mathrm{f}=42)$ were neutral. Another $20.9 \%(\mathrm{f}=67)$ of respondent strongly agreed or agreed that union and management share information freely. 
Table 2. Overall Scores on Industrial Relations Environment

\begin{tabular}{lcc}
\hline Rating & Frequency & Percent \\
Poor & 176 & 54.7 \\
Neither & 129 & 40.1 \\
Good & 17 & 5.3 \\
Total & 322 & 100.0 \\
Mean & 1.51 & \\
Std. Deviation & .597 & \\
\hline
\end{tabular}

$n=322$

Source: Survey Data 2012

In the overall analysis as indicated in Table 2, most $(54.7 \%, \mathrm{f}=176)$ of the respondents indicated that industrial relations environment was poor. On the other hand only $5.3 \%$ ( $\mathrm{f}=17$ ) reported that the industrial relations was good and $40 \%$ $(\mathrm{f}=129)$ were neutral. The study found the mean score on industrial relations environment to be 1.51 with a standard deviation of 0.597 .

These results were interpreted to mean that majority of academic staff in public universities felt that management and the union do not cooperate well neither did they confer with each other nor solve disputes amicably. Also, they thought that management did not facilitate the operations of the union, mutual regard did not exist among the parties, and management's attitude towards the union was not favorable. Besides, union did not actively participate in decision making at their place of work and management and the union did not share information freely. Overall, the result was interpreted to mean that academic staff perceived the industrial relations environment in public universities as poor.

\subsection{Factor Analysis for Industrial Relations Environment}

Exploratory factor analysis was applied to industrial relations environment variables to identify components underlying the variables. The analysis was preceded by Kaiser-Meyer-Olkin (KMO) and Bartlett's test for sphericity in order to establish the sampling adequacy for satisfactory factor analysis to proceed. The KMO measure greater than 0.5 and significant Bartlett's test is acceptable for factor analysis (Field, 2000). The Bartlett's test of sphericity was significant $(\mathrm{p}<0.05)$ and $\mathrm{KMO}(.806)$ was greater than 0.5 .

An analysis was then done to establish component score coefficients, component loading and communality. Data in Table 3 shows all components extracted from the analysis along with their component score coefficients, rotated component loading and communalities.

The values of the loading and corresponding components indicate correlations between variables and corresponding components. As shown in Table 3, it is apparent that the following variables are substantially loaded on component 1; union and management cooperates well, mutual regard between management and the union exists, union and management are willing to confer, union participates in decision making and management and union resolve disputes amicably. This suggests that these five variables define component. On the other hand, management attitude towards the union is favourable and management and the union share information freely are highly loaded on component 2 hence they define component 2 . These two components explain the industrial relations environment.

Table 3. Result of Factor Analysis on Industrial Relations Environment Variables

\begin{tabular}{lccccc}
\hline & \multicolumn{3}{l}{ Component Score } & \multicolumn{3}{c}{ Rotated Component Loading and } \\
& \multicolumn{2}{c}{ Coefficient } & \multicolumn{3}{c}{ Communalities } \\
Union and management cooperates well & $\mathrm{C}_{1}$ & $\mathrm{C}_{2}$ & $\mathrm{C}_{1}$ & $\mathrm{C}_{2}$ & $\mathrm{Com}$ \\
Mutual regard between management and the union exist & .259 & -.061 & .705 & .200 & .537 \\
union and management are willing to confer & .319 & -.147 & .778 & .101 & .615 \\
Management facilitates union operations & .333 & -.175 & .784 & .061 & .618 \\
Union participates in decision making & .101 & .186 & .536 & .503 & .540 \\
Management and union resolve disputes amicably & .226 & -.001 & .677 & .278 & .536 \\
Management attitude towards the union is favourable & .222 & .025 & .698 & .327 & .594 \\
Management and the union share information freely & -.149 & .520 & .199 & .868 & .793 \\
\hline
\end{tabular}

Key: $\mathrm{C}_{1}=$ Component $1 ; \mathrm{C}_{2}=$ Component 2 ; Com=Communalities

Source: Survey Data 2012 
The values of communalities show how much of the variance in the variable has been accounted for by extracted factors. Table 3 show that communality for management attitude towards the union is favourable was $79.3 \%$, indicating that $79.3 \%$ of variance in management attitude towards the union is accounted for by Component 1 and 2. Similarly, $80 \%$ of the variance in management and union share information freely was accounted for by Component 1 and 2 .

Analysis of total variance was then done to determine the proportion of variance in the set of variables. Table 4 shows all components extracted from the analysis along with their Eigenvalues, the percentage of variance attributed to each component, and the cumulative variance of the component and the previous components. The table indicates that two out of eight components had Eigenvalues greater than 1. In addition, the table shows that the first component accounts for $48.18 \%$ of the variance in the variables and the second component $14.725 \%$. All the remaining components are not significant. The two selected components explained $62.906 \%$ of the total variation of the variables in industrial relations environment. Component score coefficients in Table 3, were used to obtain component score values. The mean scores of component score values for the retained two components were then used as dependent variable $(Y)$ in regression analysis to determine the effect of independent variables on industrial relations environment.

Table 4. Total Variance Explained

\begin{tabular}{|c|c|c|c|c|c|c|c|c|c|}
\hline \multirow[t]{2}{*}{$\mathrm{C}$} & \multicolumn{3}{|c|}{ Initial Eigenvalues } & \multicolumn{3}{|c|}{ Extraction Sums of Squared Loadings } & \multicolumn{3}{|c|}{ Rotation Sums of Squared Loadings } \\
\hline & Total & $\%$ of $\mathrm{V}$ & CU\% & Total & $\%$ of $\mathrm{V}$ & CU \% & Total & $\%$ of $\mathrm{V}$ & CU \% \\
\hline 1 & 3.854 & 48.180 & 48.180 & 3.854 & 48.180 & 48.180 & 3.007 & 37.588 & 37.588 \\
\hline 2 & 1.178 & 14.725 & 62.906 & 1.178 & 14.725 & 62.906 & 2.025 & 25.318 & 62.906 \\
\hline 3 & .831 & 10.390 & 73.296 & & & & & & \\
\hline 4 & .622 & 7.771 & 81.067 & & & & & & \\
\hline 5 & .530 & 6.629 & 87.696 & & & & & & \\
\hline 6 & .370 & 4.630 & 92.326 & & & & & & \\
\hline 7 & .333 & 4.166 & 96.492 & & & & & & \\
\hline 8 & .281 & 3.508 & 100.000 & & & & & & \\
\hline
\end{tabular}

Source: Survey Data 2012

\subsection{Relationship of Parties to Collective Bargaining}

The analysis of relationship of parties to collective bargaining was also based on eight items which were rated on a five point Likert type scale ranging from " $1=$ strongly disagree" to " $5=$ strongly agree", with 3 being a neutral midpoint. The results in Table 4 shows that majority $(69.9 \%, \mathrm{f}=224)$ of the employees strongly disagreed or disagreed that parties were willing to consult. Only $19.1 \%(f=64)$ strongly agreed or agreed that parties to collective bargaining were willing to consult $10.6 \%(f=34)$ were neutral. On the other hand, $63.4 \%(f=204)$ of the respondents strongly disagreed or disagreed that parties to collective bargaining treat each other with respect while $14.9 \%(f=48)$ strongly agreed or agreed and $21.7 \%$ $(\mathrm{f}=70)$ were neutral.

Regarding whether parties negotiated in good faith, an overwhelming majority $(73.9 \%, \mathrm{f}=238)$ strongly disagreed or disagreed that parties to collective bargaining were negotiated in good faith. Only $10.9 \%(f=35)$ of the respondent strongly agreed or agreed that parties negotiated in good faith and $15.2 \%(f=49)$ indicated that they were neutral. In addition, 38.4\% ( $f=123)$ of respondents strongly disagreed or disagreed that employees had positive view of their representative. Almost similar percentage $(37.2 \%(\mathrm{f}=119)$ strongly agreed or agreed with the above statement while $24.45(f=78)$ reported that they were neutral. Also, 37.2\% ( $f=119)$ of the respondents strongly agreed or agreed that parties to collective bargaining were representative, while $32.5 \%$ (104) strongly disagreed or disagreed and $30.3 \%$ ( $f=97$ ) reported that they were neutral.

Further, $40.4 \%$ ( $f=130)$ of respondents strongly disagreed or disagreed that the parties to collective bargaining had negotiation skills while $28.9 \%$ ( $f=93)$ strongly agreed or agreed with that position and $30.7 \%(\mathrm{f}=99)$ were neutral. In addition, a whopping $66.7 \%(\mathrm{f}=214$ ) of the respondents strongly disagreed or disagreed that employer regards the union as a useful partner as opposed to $15.6 \%(f=50)$ who strongly agreed or agreed and $17.8 \%(f=57)$ who reported that they were neutral. Finally, 65.1\% ( $\mathrm{f}=209$ ) of respondents strongly disagreed or disagreed that parties to collective bargaining have recognition for each other. Only $21.2 \%$ ( $f=68$ ) strongly agreed with the above statement while $13.7 \%(f=44)$.

The above results were interpreted to mean that majority $(37.2 \%, \mathrm{f}=119)$ of academic staff had confidence in their 
representative to collective bargaining process and viewed the process as representative. However, an overwhelming majority $(73.9 \%, \mathrm{f}=238)$ felt that parties did not negotiate in atmosphere of good faith. In addition, between $63.4 \%(\mathrm{f}=204)$ and $69.9 \%$ (224) felt that parties did not treat each other with respect and the employer did not regard union as a useful partner in labour relation matters. Equally, they thought that parties to collective bargaining were not willing to consult and did not recognize each another.

Table 5. Analysis of Items on Relationship of Parties to Collective Bargaining

\begin{tabular}{cccccccccc}
\hline Item & SD $\%(F)$ & $\mathrm{D} \%(\mathrm{~F})$ & $\mathrm{N} \%(\mathrm{~F})$ & $\mathrm{A} \%(\mathrm{~F})$ & $\mathrm{SA} \%(\mathrm{~F})$ & $\mathrm{M}$ & $\mathrm{SD}$ & $\mathrm{S}$ & $\mathrm{K}$ \\
B1 & $11.2(36)$ & $58.4(188)$ & $10.6(34)$ & $19.9(64)$ & $0(0)$ & 2.39 & .928 & .650 & .650 \\
B2 & $10.6(34)$ & $52.8(170)$ & $21.7(70)$ & $12.1(39)$ & $2.8(9)$ & 2.44 & .933 & .761 & .761 \\
B3 & $14.3(46)$ & $59.6(192)$ & $15.2(49)$ & $8.4(27)$ & $2.5(8)$ & 2.25 & .891 & 1.055 & 1.055 \\
B4 & $4.4(14)$ & $34.1(109)$ & $24.4(78)$ & $30.9(99)$ & $6.3(20)$ & 3.01 & 1.038 & .089 & .089 \\
B5 & $2.2(7)$ & $30.3(97)$ & $30.3(97)$ & $35.0(112)$ & $2.2(7)$ & 3.05 & .910 & -.093 & -.093 \\
B6 & $2.5(8)$ & $37.9(122)$ & $30.7(99)$ & $26.4(85)$ & $2.5(8)$ & 2.89 & .912 & .229 & .229 \\
B7 & $16.5(53)$ & $50.2(161)$ & $17.8(57)$ & $13.1(42)$ & $2.5(8)$ & 2.35 & .986 & .712 & .712 \\
B8 & $9.3(30)$ & $55.8(179)$ & $13.7(44)$ & $19.0(61)$ & $2.2(7)$ & 2.49 & .975 & .703 & .703 \\
\hline
\end{tabular}

$\mathrm{n}=322$. Key: $\mathrm{SD}=$ strongly disagree; $\mathrm{D}=$ disagree; $\mathrm{N}=$ neither; $\mathrm{A}=$ agree; $\mathrm{SA}=$ strongly agree; $\mathrm{M}=$ mean; $\mathrm{SD}=$ standard deviation; $\mathrm{S}=$ skewness; K= kurtosis; F= frequency; B1= Parties are willing to consult; B2= Parties respect each other; B3= Parties negotiate in good faith; B4= Employees have positive view of their representatives; $\mathrm{B} 5=$ Parties to collective bargaining are representative; B6= Parties have negotiation skills; B7= Employer regards union as useful partner; B8= Parties have recognition for each other.

Source: Survey Data 2012

In the overall analysis, the scores on relationship of parties to collective bargaining were categorized based on the highest score (40) and the lowest score (8) on the items on the questionnaire. A score of 8 to 18 was interpreted to mean disagree (or 1). A score from 19 to 29 was interpreted to mean neither (or 2), and a score above 29 represented agree (or 3). Mean of categorized data was then computed and mean score of 1 was interpreted to suggest poor relationship of parties to collective bargaining while mean score of 2 was indicative of neither poor nor good relationship of parties. On the other hand, a mean score of 3 was interpreted to signify good relationship of parties to collective bargaining. Table 5 shows overall distribution of the frequency, percentage, mean and standard deviation of the categorized data on relationship of parties to collective bargaining items within the sample.

Table 6. Overall Scores on Relationship of Parties to Collective Bargaining

\begin{tabular}{lcc}
\hline Rating & Frequency & Percent \\
Poor & 111 & 34.5 \\
Neither & 194 & 60.2 \\
Good & 17 & 5.3 \\
Total & 322 & 100.0 \\
Mean & 1.71 & \\
Std. Deviation & 0.560 & \\
\hline
\end{tabular}

$n=322$

Source: Survey Data 2012

As indicated in Table 6, majority $(60.2 \%, \mathrm{f}=194)$ of UASU members indicated that relationship of parties to collective bargaining was neither poor nor good. An insignificant 5.3\% ( $\mathrm{f}=17)$ indicated that the relationship of parties to collective bargaining was good while $34.5 \%(\mathrm{f}=111)$ reported that it was poor. The study further found the mean score on relationship of parties to collective bargaining to be 1.71 with a standard deviation of 0.560 . This result was interpreted to signify that the relationship of parties to collective bargaining in public universities was neither good nor poor. However, union officials felt that the relationship of parties to collective bargaining was poor while the registrars felt that it was good. However, some felt that parties did not negotiate in an atmosphere of good faith. Besides, they thought that parties to collective bargaining did not have adequate negotiations kills. 


\subsection{Factor Analysis for Relationship of Parties to Collective Bargaining}

Exploratory factor analysis was applied to relationship of parties to collective bargaining variables to identify components underlying the variables. The analysis was preceded by Kaiser-Meyer-Olkin (KMO) and Bartlett's test for sphericity to establish the sampling adequacy for factor analysis to proceed. The result of the test shows that the Bartlett's test of sphericity was significant $(p<0.05)$ and $\mathrm{KMO}(.804)$ was greater than 0.5 .

An analysis was then performed to establish component score coefficients, component loading and communality. Data in Table 7 reveals that the following variables are substantially loaded on component 1; parties respect each other, parties negotiate in good faith, parties are willing to consult, parties have recognition for each other and employer regards union as useful partner. Hence these variables define the component. On the other hand; parties to collective bargaining are representative, employees have positive view of their representatives and parties have negotiation skills are highly loaded to component 2. The component is therefore defined by these variables.

Also, the table shows that communality for parties to collective bargaining are representative was $73.0 \%$, indicating that $73.0 \%$ of variance in parties to collective bargaining are representative was accounted for by Component 1 and 2. Similarly, 67.5\% of the variance in Parties respect each other was accounted for by Component 1 and 2.

Table 7. Result of Factor Analysis on Relationship of Parties to Collective Bargaining

\begin{tabular}{lcccccc}
\hline & \multicolumn{3}{c}{ Component } & \multicolumn{3}{c}{ Rotated Component } \\
& \multicolumn{2}{c}{ Score Coefficient } & \multicolumn{2}{c}{ Loading and Communalities } \\
& $\mathrm{C}_{1}$ & $\mathrm{C}_{2}$ & $\mathrm{C}_{1}$ & $\mathrm{C}_{2}$ & $\mathrm{Com}$ \\
Parties are willing to consult & .256 & .016 & .670 & .303 & .540 \\
Parties respect each other & .374 & -.132 & .817 & .090 & .675 \\
Parties negotiate in good faith & .400 & -.204 & .808 & -.046 & .654 \\
Employees have positive view of their representatives & -.109 & .404 & .144 & .805 & .669 \\
Parties to collective bargaining are representative & -.132 & .433 & .115 & .847 & .730 \\
Parties have negotiation skills & -.062 & .349 & .206 & .729 & .574 \\
Employer regards union as useful partner & .193 & .060 & .557 & .339 & .425 \\
Parties have recognition for each other & .216 & .077 & .631 & .400 & .558 \\
\hline
\end{tabular}

No. 322. Key: C1=component 1; C2= component 2; Com=Communalities

Source: Survey Data, 2012

Analysis of total variance was then done to determine the proportion of variance in the set of variables. Table 8 shows all components extracted from the analysis along with their Eigenvalues, the percentage of variance attributed to each component, and the cumulative variance of the component and the previous components. The result indicates that two out of eight components had Eigenvalues greater than 1. In addition, the result demonstrates that the first component accounts for $43.313 \%$ of the variance and the second component $17.007 \%$. All the remaining components are not significant. The retained two components explained $60.321 \%$ of the total variation of the variables in relationship of parties to collective bargaining.

Table 8. Total Variance Explained

\begin{tabular}{ccccccccc}
\hline C & \multicolumn{3}{c}{ Initial Eigenvalues } & \multicolumn{3}{c}{ Extraction Sums of Squared } \\
Loadings & \multicolumn{3}{c}{ Rotation Sums of Squared } \\
Loadings
\end{tabular}

Key: $\mathrm{V}=$ variance; $\mathrm{CU}=$ cumulative; $\mathrm{C}=$ component

Source: Survey Data, 2012 
Component score coefficients in Table 7 were used to obtain component scores values. The mean scores of component score values for the retained two components were then used as independent variable $(X)$ in regression analysis to determine the effect of parties to collective bargaining on industrial relations environment.

\section{Result of Multiple Regression Analysis}

In regression analysis, the component mean score values for retained two components of industrial relations environment were regressed against the component mean score values of the retained components of relationship of parties to collective bargaining. The results in Table 9 demonstrate that relationship of parties to collective bargaining had a significant effect on industrial relations environment $(\beta=0.531, p<0.05)$. Also, that relationship of parties to collective bargaining made a positive contribution to industrial relations environment. This means that that relationship of parties to collective bargaining has a positive effect on industrial relations environment in public universities in Kenya.

Table 9: Regression analysis of industrial relations environment and relationship of parties to collective bargaining

\begin{tabular}{|c|c|c|c|c|c|c|c|}
\hline \multirow[b]{3}{*}{ (Constant) } & \multicolumn{2}{|c|}{$\begin{array}{l}\text { Unstandardized } \\
\text { Coefficients }\end{array}$} & \multirow{2}{*}{$\begin{array}{c}\text { Standardized } \\
\text { Coefficients } \\
\text { Beta }\end{array}$} & \multirow[t]{2}{*}{$\mathrm{t}$} & \multirow[t]{2}{*}{ Sig. } & \multicolumn{2}{|c|}{ Collinearity Statistics } \\
\hline & B & Std. Error & & & & Tolerance & VIF \\
\hline & .008 & .034 & & .065 & .948 & & \\
\hline$x$ & .528 & .048 & .531 & 10.042 & .000 & 1.000 & 1.000 \\
\hline
\end{tabular}

a. Dependent Variable: $Y, N=322$

Source: Survey data 2012,

\section{Discussion of Findings}

The objective of the study was to determine the effect of relationship of parties to collective bargaining on industrial relations environment in public universities in Kenya. The results demonstrate that the absence of mutual regard among parties, cooperation between the union and management failure to facilitate union operations is likely to lead to poor industrial relations environment. Similarly, where management and the union fail to resolve disputes amicably and management's attitude towards the union is not favorable, the industrial relations environment is likely to be poor. This also applies to where the union does not participate in decision making and management does not confer or share information freely with the union.

On the other hand, the study found that employees perceived the relationship of parties to collective bargaining to be poor. Majority of academic staff indicated that employer and the union were not willing to consult, they did not recognize and respect each other and, they did not negotiate in an atmosphere of good faith. Besides, they viewed parties to collective bargaining as not representative and the employer did not regard the union as a useful partner in collective bargaining process. Equally, respondents felt that parties to collective bargaining did not have adequate negotiation skills though they had a positive view of their representatives.

Further, the study revealed that relationship of parties to collective bargaining had a significant and positive effect on industrial relations environment. This was interpreted to mean that the manner in which parties to collective bargaining manage their relationship determines the outcome of industrial relations environment in an organization.

These finding are consistent with the broader literature which has shown the importance of the willingness of parties to consult, treating each other with respect, bargaining in atmosphere of good faith, representation, mutual recognition and partnership in influencing industrial relations environment in an organization (Fashoniy, 2004; Pyman et al., 2010; Bryson et al., 1998; Wan et al., 1997; Foster et al., 2009; Peetz and Frost, 2007; Jain et al., 2004). For instance, Pyman et al. (2010) in their study suggested that for sound industrial relations, the employers should regard their employees and union representatives as useful partners. Similarly, a study by Peetz and Frost (2007) revealed that existence of mutual recognition is also prerequisites of co-operative relationships.

It therefore follows that, for collective bargaining to be effective, a constructive relationship and partnership must be established by parties to collective bargaining. Besides, parties must negotiate in good faith, treat each other with respect and have mutual regard for each other. This will then support the enhancement of industrial relations environment. From the above findings, it is apparent that the union and the employer are working on across purpose since they seem to be pulling in different directions. Evidence from the above studies indicate that, an environment that 
makes cooperation between employer and union difficult leads to poor industrial relations environment in an organizations.

\section{Conclusions}

On the basis of these findings it is evident that relationship of parties to collective bargaining had a positive statistically significant effect on industrial relations environment. The therefore affirms the validity of the assertion that relationship of parties to collective bargaining has a significant effect on industrial relations environment. The study shows that academic staff felt that the relationship of parties to collective bargaining was poor hence affecting the industrial relations environment. It is suggested that the establishment of a constructive relationship and partnership among the parties could reverse this scenario. The study therefore reaffirms that understanding how parties to collective bargaining relate to each other, is very critical in determining industrial relations environment in organisations.

The research consequently contributes to advancement of knowledge on industrial relations from the African context and particularly on universities in Kenya.

\section{References}

Anderson, C., Gunderson, M. \& Ponak, A. (1989). Union-management relations in Canada. $2^{\text {nd }}$ Ed. Canada: Addison-Wesley Publishers.

Armstrong, M. (2006). A Handbook of human resource management practice. 10 $0^{\text {th }}$ Ed. London: Kogen Page limited.

Boxall, P. \& Macky, K. (2009). Research and theory on high-performance work systems: progressing the high-involvement stream. Human Resource Management Journal, 19.1, 3-23

Bryson, A. \& Freeman, B. (2007). "What workers say: employee voice in the Anglo-American workplace." What voice do British workers want? Eds. Richard B. Freeman, Peter Boxall and Paul Haynes, Ithaca, NY: Cornell University Press: 72-96

Caverley, N., Cunningham, B. \& Mitchell, L. (2006). "Reflections on public sector-based integrative collective bargaining conditions affecting cooperation within the negotiation process." Employee Relations, 28.1, 62-75.

Dubin, R. (1957). "Power and Union-management relations: administrative science." Quarterly, 2. 1, 60-81.

Dunlop, J.T. (1958). Industrial relations systems. New York: Holt.

Egels-Zandén, N.\& Hyllman, P. (2009). Translating competing models

of industrial relations local bargaining versus global rules in the Swedish clean clothes campaign. Available: http://www.helsinki.fi/project leva/ncr/egels- zanden hyllman.pdf (September 15, 2010).

Farnham, D. (2000). Employee relations in context. London: Institute of Personnel and Development.

Fashoyin, T. (2004).Tripartite cooperation, social dialogue and national development. International Labour Review, 143, 343-372.

Fiorito, J. (2011). Industrial relations. References for Business Encyclopedia of Business. 2n Ed. Available: http://www.referenceforbusiness.com /encyclopedia/Inc-Int/Industrial-Relations.html (April 3, 2011).

Flippo, E.B. (1984). Personnel management. London: McGraw-Hill.

Foster, B., Murrie, J. \& Laird, I. (2009). "It takes two to tango: evidence of a decline in institutional industrial relations in Newzealand." Employee Relations, 31.5, 503-514.

Gatchalian, J. C. (1998). Principled negotiations - a key to successful collective bargaining. Management Decision, 36.4, 222-225.

Goolsarran, S. J. (2006). Industrial Relations in the Caribbean, Issues and Perspectives. International Labour Organization.

Greene, A., Black, J. \& Ackers, P. (2000). "The union makes us strong? A study of the dynamics of workplace union leadership at two UK manufacturing plants." British Journal of Industrial Relations, 38. 1, 75-93.

Guest, D. \& Peccei, R.(2001). "Partnership at work: mutuality and the balance of advantage". British Journal of Industrial Relations, 39. 2, 207-236.

ILO/PROMALCO Product (2005). Building labour-management partnerships - a practical guide; tools for the high road to productivity and international competitiveness. Available File://D:/manual01?m1_17.htm ( April 23, 2009).

Jain, N.C and Saakshi,J. (2004). Personnel management and human resources. New Delhi, India: All India Travellers Bookseller.

Kersley, B., et al. (2006). Inside the workplace: Findings from the 2004 workplace employment relations survey (WERS). London: Routledge.

Khan, A. M. (2006). Adjudication in industrial disputes - the case of Trinidad and Tobago. ILO.

Kuruvilla, S. \& Erickson, C. L. (2002). "Change and transformation in Asian industrial relations." Industrial Relations, 41.2, 171-228.

Lee, J. \& Lee, D. (2009). Labor-management partnership at Korean firms: Its effects on organizational performance and industrial relations quality. Personnel Review, 38 .4, 432-452.

Mahabir-Wyatt, D (2006). The state in industrial relations. ILO.

Peetz, D. \& Frost, A. (2007). "What workers say: employee voice in the Anglo-American workplace." Employee voice in the AngloAmerican world: what does it mean for unions? Eds. R. B. Freeman, P. Boxall and P. Haynes Ithaca, NY: Cornell University Press: $166-80$

Pyman, A., Holland, P., Teicher, J., \& Cooper, B. K. (2010). "Industrial relations climate, employee voice and managerial attitudes to 
unions: An Australian Study." Journal of Industrial Relations ,48.2, 460-480

Redman, T. R., \& Snape, E. (2006). Industrial relations climate and staff attitudes in the fire Service: A Case of union renewal? Employee Relations, 28. 1, 26-45.

Rehman, Shafiq (2003). "Collective bargaining and wage determination in Pakistan." PhD Dissertation University of Karachi

Sealy, H. (2003). Country Paper on Collective Bargaining in the Public Service Barbados, Caribbean Sub-regional Seminar on Employment and Collective Bargaining in Civil Service. Antigua and Barbuda. Available: http://www.unpan1.un.org/intradoc I.../public/.../UNPAN010845 (May 10, 2010)

Silva, S.R. (1998). Elements of a sound industrial relations system. East Asia multidisciplinary advisory team. ILO: Bangkok.

Wan, D., Haut, O. C, \& Yuee, L. H. (1997). Industrial Relations climate in the manufacturing sector in Singapore. Journal of Management, 14, 123-141. 